\title{
The influence of sex steroid hormones on the response to trauma and burn injury
}

\author{
K Al-Tarrah ${ }^{1,2^{*}}$ (D, N Moiemen ${ }^{2}$ and JM Lord ${ }^{1 *}$
}

\begin{abstract}
Trauma and related sequelae result in disturbance of homeostatic mechanisms frequently leading to cellular dysfunction and ultimately organ and system failure. Regardless of the type and severity of injury, gender dimorphism in outcomes following trauma have been reported, with females having lower mortality than males, suggesting that sex steroid hormones (SSH) play an important role in the response of body systems to trauma. In addition, several clinical and experimental studies have demonstrated the effects of SSH on the clinical course and outcomes following injury. Animal studies have reported the ability of SSH to modulate immune, inflammatory, metabolic and organ responses following traumatic injury. This indicates that homeostatic mechanisms, via direct and indirect pathways, can be maintained by SSH at local and systemic levels and hence result in more favourable prognosis. Here, we discuss the role and mechanisms by which SSH modulates the response of the body to injury by maintaining various processes and organ functions. Such properties of sex hormones represent potential novel therapeutic strategies and further our understanding of current therapies used following injury such as oxandrolone in burn-injured patients.
\end{abstract}

Keywords: Burn, Trauma, Sex hormones, Sex steroid hormones, Testosterone, Estradiol, Oestrogen

\section{Background}

There has been increasing interest in the role of the endocrine system in the pathophysiological response to major trauma, with several studies suggesting that sex steroid hormones (SSH) may influence the outcome after injury. Survival differences have been reported between males and females after major trauma, with female victims having lower mortality than males $[1,2]$. Morbidity is also affected by gender and as early as 1975, McGowan et al. reported a significantly higher incidence of bacteraemic infections in male trauma patients compared to females, $58.5 \%$ vs $41.5 \%$ respectively [3]. In addition, adults show a gradual decrease in survival after traumatic injury with age [4]. This further suggests that the reduction in sex hormone, as a result of menopause and andropause, may influence the response to injury [5].

This review discusses the potential role of SSH in explaining gender and age differences in mortality and post-injury pathology and potential novel treatment

\footnotetext{
* Correspondence: kxa455@bham.ac.uk; J.M.Lord@bham.ac.uk ${ }^{1}$ Institute of Inflammation and Ageing, Birmingham University Medical School, B15 2TT, Birmingham, UK

Full list of author information is available at the end of the article
}

strategies that target the endocrine response and may improve outcomes following trauma.

\section{Review \\ Impact of gender on outcomes after trauma}

Despite advances in medical care, sepsis and subsequent multiple organ failure (MOF) continue to be a major cause of morbidity and mortality in trauma patients [6], but there is evidence of gender differences for sepsis, MOF and mortality. In a study of 681,000 trauma patients, females demonstrated significantly lower complications and mortality rates compared to males [1]. A recent meta-analysis of 100,566 male and 39,762 female trauma patients found male gender was associated with higher incidence of complications, lengthier hospital stay and increased mortality [7]. In addition, male gender has been identified as a risk factor in the development of infection and MOF [8-10] and males suffer from significantly lower survival rates following sepsis when compared to females, $31 \%$ vs $74 \%$ [11]. This suggests that SSH may play a role in the maintenance of immune-inflammatory function in the trauma setting. This is further supported by the work of Haider et al. who concluded that females aged 13-64 exhibited significantly lower mortality outcomes following trauma- 
associated shock when compared to males and that this difference was abolished in the extremes of age when the effects of sex hormones were either absent or diminished [12]. Trentzsch et al., who performed a matchedpair analysis of 29,353 prospectively recorded trauma cases, concluded that males were more susceptible to MOF, sepsis and mortality [13].

Female patients appear to benefit from better physiological reserves and thereby are more protected against the consequences of trauma and shock. A prospective clinical study reported that female trauma patients required less fluid resuscitation volumes $(12 \mathrm{~L}$ vs $8 \mathrm{~L}$, $P<0.05)$, less Starling curve intervention $(42 \%$ vs $15 \%$, $P<0.05)$ to maintain oxygen delivery index and less inotrope and/or vasopressor support ( $36 \%$ vs $10 \%, P<0.05$ ) compared with similarly injured male patients and a standardized management protocol [14]. Another prospective clinical study involving more than 4000 patients reported that premenopausal women exhibited lower serum lactate levels and required less blood transfusion despite having more severe injuries [15].

However, the role of gender in modifying the response to trauma is still not clear-cut, with multiple conflicting clinical reports in the literature. Rappold et al. concluded that the female gender offered no protection from the development of acute respiratory distress syndrome, pneumonia or sepsis nor was it associated with decreased mortality rates post-trauma [16]. This finding was replicated by other studies which have demonstrated equivalent mortality rates in both genders following traumatic injury [17-19]. Other studies have suggested that female gender is a risk factor in trauma patients and is associated with increased complication and mortality rates [20-22]. These conflicting findings may be attributed to many factors such as study sample size, triage, treatment speed, and management protocol.

This apparent lack of agreement in the literature highlights the need for further studies in better controlled environments, comparing similar types of injury and taking age and gender into account in order to obtain more conclusive data. In addition, there remains a paucity of data on the mechanisms that may underlie gender differences in humans, with the majority of such research done in animal models of trauma. In this review, we therefore discuss the potential impact of gender and SSH on different aspects of the response to trauma, and we have made it clear where the data rely almost entirely on animal studies.

\section{Effect of SSH on the immune and inflammatory response to trauma}

Various clinical and experimental studies have demonstrated that gender influences both humoral and cellmediated immune responses and SSH receptors have been identified in multiple lymphoid tissues such as the bone marrow, spleen and thymus, as well as in different immune cells including lymphocytes, mast cells, granulocytes and macrophages [23]. Trauma has been shown to lead to immune dysfunction which, in turn, is associated with increased susceptibility to sepsis, MOF and mortality [24-27]. The processes driving immuneparesis after trauma are complex and include the cytokine storm elicited by tissue damage, which includes concomitant release of pro- and anti-inflammatory cytokines and the suppression of a variety of cell-mediated immune responses, which we have reviewed previously [5]. This immune suppression is mediated largely by the effects of cortisol released as a result of activation of the hypothalamicpituitary-adrenal axis, but there is evidence that sex hormones represent an additional influence.

Wichmann et al. reported significant gender differences in B lymphocyte, $\mathrm{T}$ lymphocyte and natural killer (NK) cell counts following surgery despite comparable preoperative cell counts [28], with men showing reductions in cell numbers for up to 5 days. In addition, women exhibited a more pronounced pro-inflammatory response, with elevated circulating interleukin (IL)-6 levels, post-operatively [28]. Conversely, other studies have observed increased levels of IL-6, tumour necrosis factor-alpha (TNF- $\alpha$ ) and procalcitonin in male trauma patients compared to females $[29,30]$. What may be pertinent are the ratio of pro- to anti-inflammatory cytokines and the chronicity of the response: a profound initial inflammatory response may favour prevention of infection, but if inflammation is not resolved promptly, this can prevent wound healing and lead to organ damage.

Experimental studies in animal models of trauma have shown the modulation of immune responses by sex hormones. Overall testosterone appears to have antiinflammatory and immunosuppressive effects, promoting synthesis of anti-inflammatory cytokines such as IL10 by murine macrophages [31], reducing NK cell activity and the synthesis of pro-inflammatory cytokines, such as TNF- $\alpha$, via the inhibition of nuclear factor kappa $\mathrm{B}(\mathrm{NF \kappa B})$ [32, 33]. Testosterone has also been associated with decreased expression on macrophages and monocytes of toll-like receptor 4 (TLR4) which is involved in the activation of the innate immune system and production of inflammatory cytokines [34] by damageassociated molecular patterns (DAMPs).

Progesterone also exerts an immunosuppressive effect by inhibiting the activation of $\mathrm{NFK}_{\mathrm{K}} \mathrm{B}$ and increasing the expression of suppressor of cytokine signalling protein 1 (SOCS1) [35]. In addition, progesterone reduces the activity of macrophages and NK cells, as well as the synthesis of antibodies by B cells [36-39]. Elevated levels of progesterone during pregnancy have been associated with decreased development of pro-inflammatory helper $\mathrm{T}$ cell 
type 1 (Th1) immune responses while promoting the immune responses of Th2 including the synthesis of antiinflammatory cytokines such as IL-4, IL-5 and IL-10 [40].

In contrast, estradiol has typically been shown to enhance cell-mediated and humoral immune responses. It augments NK cell cytotoxicity, as well as stimulating the production of pro-inflammatory cytokines including IL$1 \beta$, IL- 6 and TNF- $\alpha[38,41]$ and inhibits the synthesis of anti-inflammatory cytokines such as IL-10 [42]. In addition, oestrogens have been shown to increase survival and prevent apoptosis of immune cells [43, 44]. The balance of sex hormones in the circulation may thus be a key modulator of immune responses to trauma and tissue injury in humans.

Several murine studies have shown depressed immune responses in males as well as oophorectomized and aged females following trauma, haemorrhage and sepsis $[45,46]$. Interestingly, pretreatment of female mice with 5-dihydrotestosterone (DHT) prior to trauma-haemorrhage resulted in depressed macrophage function and reduced levels of cytokines comparable to that seen in males $[47,48]$. Moreover, castration and depletion of male sex hormones prior to trauma-haemorrhage resulted in enhanced immune responses [49-51]. In contrast, female sex hormones are associated with enhanced cell-mediated immune responses to trauma. Elevated systemic levels of estradiol in proestrus female mice played a pivotal role in post-trauma and haemorrhage immunocompetence [52]. Furthermore, administration of $17 \beta$-estradiol (E2) was associated with improved survival rates in animal models of sepsis [53]. A single dose of estradiol following traumahaemorrhage and resuscitation was shown to restore depressed immune responses [54].

In animal studies, the effect of SSH on splenic immune response has been evaluated with studies demonstrating that E2 played a critical role in restoring splenic macrophage and immune functions post-injury by depressing pro-inflammatory cytokine production $[52,55]$. Furthermore, Knoferl et al. reported that splenocyte proliferation and the release of IL-2, IL-3 and interf eron-gamma (IFN- $\gamma$ ) were suppressed in oophorectomised females following trauma-haemorrhage to levels comparable to those observed in males [52]. Moreover, castration prior to injury attenuated the depression of major histocompatibility complex (MHC) II (Ia) expression in mice, thereby improving cell-mediated immunity [56]. Oestrogen enhances splenic macrophage (TNF- $\alpha$ and IL-6) and T lymphocyte (IL-2 and IL-6) cytokine secretion following trauma [57-59]. In addition, E2 and estrogen receptor alpha (ER- $\alpha)$ agonist prevented the apoptosis of splenic dendritic cells and attenuated the depression of splenic dendritic cell cytokine production, co-stimulating factors and MHC II expression as well as antigen presentation capacities [60]. These effects of E2 on splenic function appear to be predominantly mediated via ER- $\alpha[59,60]$. This protective role of female sex hormones is associated with significantly increased survival rates in animal models [52].

Clinical studies investigating the effect of SSH on the immune-inflammatory cascade following trauma are more limited. Male patients of virtually all age groups have been reported to have higher incidence of sepsis following trauma and haemorrhagic shock suggesting the immunosuppressive effect of testosterone [61]. In addition, Zolin et al. reported that early elevations and increasing levels of testosterone over the initial 24-h period after injury were associated with an exaggerated inflammatory response and significantly increased risk of nosocomial infections and MOF. Interestingly, high circulating levels of estradiol at $24 \mathrm{~h}$ were associated with a fourfold greater risk of developing MOF [62]. Another study observed negative correlations between estradiol levels and TNF- $\alpha$ on day 1 and day 2 following trauma. However, no significant relationships were identified between SSH levels and IL-6, IL-8 or leukocyte counts [63]. Moreover, Lopez et al. concluded that while there is sexual dimorphism in the leukocyte genomic response following severe injury that are associated with more severe and prolonged organ failure, these differences were not in sex-linked genes or linked to differences in systemic levels of cytokines and therefore do not translate into sex-specific organ dysfunction or 28-day inhospital mortality [64].

The overall picture in relation to the impact of gender of the immune-inflammatory response to trauma and potential impact on outcomes such as sepsis, is one of a protective immune-enhancing role of oestrogens and a contrasting immunosuppressive effect of androgens. However, most data are derived from animal studies with very few studies in humans, and there is thus a need for clinical research and RCTs to determine benefits of SSH in maintaining immune competence after trauma.

\section{Effects of SSH on body systems after trauma}

The actions of androgens, oestrogens and progestins are mediated through genomic and non-genomic pathways. The widespread expression of SSH receptors in tissues means that they have very broad effects on tissue and organ function, which may explain gender differences in trauma outcomes such as MOF (Table 1).

\section{Cardiovascular system}

Trauma and haemorrhage are known to induce myocardial dysfunction, decreasing cardiac output and blood flow $[65,66]$. This effect is exacerbated in male mice, and castration 2 weeks prior to trauma and haemorrhage attenuates the depression of myocardial function [67]. Furthermore, treatment of male mice subjected to 
Table 1 Summary of the effects of oestrogen and testosterone on various organs

\begin{tabular}{|c|c|c|c|c|}
\hline \multirow[t]{2}{*}{ Organ } & \multicolumn{2}{|l|}{ Oestrogen } & \multicolumn{2}{|l|}{ Testosterone } \\
\hline & Effect & References & Effect & References \\
\hline Heart & $\begin{array}{l}\text { - Improved left ventricular function } \\
\text { - Improved cardiac output } \\
\text { - Enhanced p38MAPK, Akt, } \\
\text { eNOS and HSP } \\
\text { expression } \\
\text { - Reduction in IL-6, NFKB } \\
\text { and TNF-a }\end{array}$ & [70-79] & $\begin{array}{l}\text { - Depressed myocardial function } \\
\text { - Suppression of Akt anti-apoptotic } \\
\text { pathways } \\
\text { - Reduced expression of Bcl-2 } \\
\text { - Chronic administration } \\
\text { improves function } \\
\text { and reduces tissue damage }\end{array}$ & [80-82] \\
\hline Lungs & $\begin{array}{l}\text { - Decreased lung congestion, } \\
\text { oedema and } \\
\text { inflammation } \\
\text { - Decreased emphysematous changes } \\
\text { - Enhanced eNOS/PKG expression } \\
\text { - Decreased KDC, MIF, TLR-4 and } \\
\text { ERK expression } \\
\text { - Reduction in IL-6, TNF-a, ICAM-1, } \\
\text { CINC-1 and MIP-2 }\end{array}$ & {$[87,105-110,159]$} & $\begin{array}{l}\text { - Increased lung permeability } \\
\text { and inflammation } \\
\text { - Increased nitric oxide levels }\end{array}$ & [45] \\
\hline Liver & $\begin{array}{l}\text { - Reduction in liver congestion, portal } \\
\text { inflammation and focal necrosis } \\
\text { - Enhanced Kupffer cell function } \\
\text { - Reduction in IL-6, TNF-a, } \\
\text { MIP-1a and MIP-2 } \\
\text { - Increased expression of Bcl-2 } \\
\text { - Reduced ET-1 response }\end{array}$ & {$[68,71,87-96]$} & $\begin{array}{l}\text { - Reduced hepatic microvascular } \\
\text { blood flow } \\
\text { - Diminished hepatocellular } \\
\text { function }\end{array}$ & [97] \\
\hline Spleen & $\begin{array}{l}\text { - Stimulation of splenocyte proliferation } \\
\text { - Increased IL-2 and IL-3 } \\
\text { - Improved splenic macrophage } \\
\text { and T lymphocyte function } \\
\text { - Prevented apoptosis of splenic } \\
\text { dendritic cells } \\
\text { - Improved splenic dendritic cell function } \\
\text { - Enhanced MHC II expression }\end{array}$ & {$[52,55-60]$} & $\begin{array}{l}\text { - Reduces MHC II expression } \\
\text { - Depressed cell-mediated } \\
\text { immune response }\end{array}$ & [56] \\
\hline Intestines & $\begin{array}{l}\text { - Reduced ET-1 response } \\
\text { - Enhanced p38MAPK and Akt expression } \\
\text { - Reduction in MPO, ICAM-1, CINC-1, } \\
\text { CINC-3, MIP-2 and IL-6 }\end{array}$ & [101-104] & $\begin{array}{l}\text { - Enhances local pro-inflammatory } \\
\text { response }\end{array}$ & {$[45,97,98]$} \\
\hline Brain/Nerves & $\begin{array}{l}\text { - Reduced iNOS expression } \\
\text { - Reduction in hypothalamic TNF-a } \\
\text { - Preservation of blood brain } \\
\text { barrier integrity } \\
\text { - Inhibition of MMP-2 and MMP-9 }\end{array}$ & [113-117] & $\begin{array}{l}\text { - Inhibition of caspase-3, MPO } \\
\text { and XO activity } \\
\text { - Reduction in malondialdehyde } \\
\text { - Increased catalase levels } \\
\text { - Maintains cellular and } \\
\text { structural integrity } \\
\text { - Preserves neural function }\end{array}$ & [118-120] \\
\hline Kidneys & $\begin{array}{l}\text { - Enhanced Akt and eNOS expression } \\
\text { - Reduction in neutrophil infiltration }\end{array}$ & {$[127,128]$} & $\begin{array}{l}\text { - Reduced NOS, Akt and ERK expression } \\
\text { - Low doses: increased IL-10 } \\
\text { and reduction in T cell infiltration }\end{array}$ & {$[125,126]$} \\
\hline
\end{tabular}

MAPK Mitogen-activated Protein Kinase; eNOS endothelial Nitric Oxide Synthase; HSP Heat Shock Protein; IL Interleukin; NFKB Nuclear Factor Kappa B; TNF- $a$ Tumour Necrosis Factor-alpha; PKG Protein Kinase G; KDC Keratinocyte-derived Chemokines; MIF Migration Inhibitory Factor; TLR Toll-like Receptor; ICAM Intracellular Adhesion Molecule; CINC Cytokine-induced Neutrophil Chemoattractant; MIP; Macrophage Inflammatory Protein; BCl-2 B-cell lymphoma-2; ET Endothelin; MHC Major Histocompatibility Complex; MPO Myeloperoxidase; iNOS inducible Nitric Oxide Synthase; MMP Matrix Metalloproteinase

trauma and blood loss with an androgen receptor antagonist resulted in improved cardiovascular function [68]. In contrast, proestrus females have shown better regulation of cardiac function and blood volumes following trauma-haemorrhage when compared to males, with significant improvements in cardiac output and performance as well as increased circulating blood volume [69]. This effect may explain the improved restoration of organ function seen in proestrus female mice subjected to such injury [70].

In rodent studies, administration of E2 following trauma and haemorrhage significantly improved left ventricular function and cardiac output and prevented the increase of plasma IL-6 levels [71]. Furthermore, oestrogen has been shown to decrease IL- 6 and NFKB in cardiomyocytes post-injury via inhibiting the expression and activity of hypoxia-inducible factor (HIF)- $1 \alpha$, resulting in improved cardiac function [72]. This inverse correlation between cardiomyocyte IL- 6 levels and cardiac function was also reported by Yang et al. [73]. In addition, administration of E2 following trauma and haemorrhage increased the expression and activity of heme oxygenase (HO)-1 [74], mediated via the p38 mitogen-activated protein kinase (MAPK) pathway and subsequent phosphorylation of HSP-27 and $\alpha \beta$-crystallin [75]. Heat shock proteim (HSP)-27 and $\alpha \beta$-crystallin are known to prevent apoptosis during periods of stress, and Kan et al. showed that p38MAPK activation exerted 
further tissue protective effects through the increased expression and phosphorylation of endothelial NO synthase (eNOS) [76]. Furthermore, the cardioprotective properties of HO-1 post-oestrogen administration can also be achieved through Akt phosphorylation [77], which is also associated with inhibition of cardiomyocyte apoptosis [78, 79].

Testosterone has demonstrated both protective and detrimental cardiac effects following ischemic reperfusion insult in rodents. Acute testosterone replacement had adverse effects on myocardial function following injury, thought to be secondary to the inhibition of signal transducers and activators of transcription 3 (STAT-3) and suppression of cytokine signalling 3 (SOCS-3) antiapoptotic pathways, as well as downregulation of Akt anti-apoptotic pathways that results in depressed myocardial function [80, 81]. In contrast, chronic testosterone therapy at physiological doses was effective at reducing infarct size, improving cardiac contractility, reducing arrhythmias, and improving myocyte viability as well as enhancing autonomic myocardial regulation following injury [82].

In addition to their effects on the myocardium, $\mathrm{SSH}$ has also been reported to modulate coagulation within the vasculature. A plethora of studies have implicated hormone replacement therapy and hormone-based contraceptives with promoting coagulation [83, 84]. Interestingly, female trauma patients were reported to be hypercoagulable on day 1 following injury compared to male trauma patients [85]. Furthermore, Gee et al. reported that early circulating estradiol-progesterone ratio levels positively correlated with thromboelastographic parameters and partial thromboplastin times and hence favouring a hypercoagulable state [63]. This early hypercoagulable state may in part explain why females presenting with acute traumatic coagulopathy following injury have been reported to have significantly poorer outcomes and twofold higher independent risk of mortality [86].

The influence of SSH on the human cardiovascular system following trauma is still poorly understood. Even though the observations from animal models appear promising, large-scale observational studies investigating various cardiovascular and hormone parameters of both genders as an initial step may prove insightful about the role of SSH on the human response to injury.

\section{Gastrointestinal system}

Following sepsis, female rats show less systemic endotoxemia and liver tissue damage than males and treatment with oestrogen and progesterone reduced liver congestion, portal inflammation and focal necrosis [87]. Administration of estradiol or androgen antagonist flutamide was associated with improved hepatocellular function following shock $[68,71]$. This may be partly explained by the effect E2 exerts on Kupffer cells (KC). KCs are a major source of pro-inflammatory cytokines in the liver. Estradiol has been reported to enhance $\mathrm{KC}$ phagocytic capacity and depress cytokine production including IL-6, TNF- $\alpha$, macrophage inflammatory protein (MIP)-1 $\alpha$ and MIP-2 [88-91]. This is achieved via downregulation of TLR4-dependent p38MAPK and NFkB phosphorylation, while stimulating Akt activation and enhancing HO-1 expression [90, 92-94]. These beneficial effects of E2 on KC functions are mediated predominantly through ER- $\alpha$ [95], though a role for G proteincoupled receptor (GPR)-30, which activates protein kinase $\mathrm{A}$ (PKA) and increases expression of anti-apoptotic protein B-cell lymphoma-2 (Bcl-2) has been shown [96]. In contrast, testosterone had a deleterious effect following gut injury by producing pro-inflammatory and tissue toxic effects in mesenteric lymph nodes [97]. This negative impact of androgens is further supported by studies demonstrating that testosterone depletion ameliorated the magnitude of gut injury in animal models [45, 97, 98].

Maintenance of organ perfusion is essential to ensure organ vitality. The response to endothelin (ET)-1, a potent vasoconstrictor, is enhanced following shock, which subsequently further impairs circulation and induces organ damage. Estradiol administration post-injury attenuated ET-1 responses improving liver and intestinal perfusion $[99,100]$. In addition, estradiol attenuated intestinal injury by modulating myeloperoxidase activity, TNF- $\alpha$, IL-6, intracellular adhesion molecule (ICAM)-1, cytokine-induced neutrophil chemoattractant (CINC)-1, CINC-3 and macrophage inflammatory protein (MIP)-2 levels by enhancing p38MAPK and Akt pathways [101, 102]. Interestingly, treatment with the androgen antagonist flutamide exerted similar effects [103, 104].

There are currently no human studies investigating the influence of $\mathrm{SSH}$ on the gastrointestinal system following trauma.

\section{Other body systems}

Rodent studies have demonstrated gender dimorphism in responses of various organs to injury. Caruso et al. concluded that lung protection against injury was greatest during the estrus and proestrus stages of the menstrual cycle and decreased during the diestrus stage [105]. Furthermore, oestrogen and progesterone administration attenuated emphysematous and inflammatory changes in the lung as well as improved congestion and oedema following sepsis [87]. Tominaga et al. showed that oophorectomized animals displayed a 2.6 -fold increase in vascular permeability following ioxaglate treatment (a contrast medium that increases vascular permeability) compared to controls and that this effect was blocked following estradiol administration [106]. 
These effects may be secondary to the decreased expression of keratinocyte-derived chemokines (KDC), migration inhibitory factor (MIF) and TLR-4, which in turn reduces cytokine/chemokine production and neutrophil infiltration, reducing oedema formation and subsequent organ damage $[107,108]$. These protective properties of E2 are mediated via the extracellular signal-regulated protein kinase and eNOS pathways [109, 110]. In contrast, male rats displayed increased trauma-shockinduced lung injury with increased nitrite/nitrate production, hence demonstrating the potential injurious role of male SSH [45].

Research in animal models has also indicated differential neuroendocrine-immune responses between genders following neurotoxaemia. Administration of E2 abolished most of the gender dimorphic responses including hyperglycaemia, hypercorticosteronaemia and hypercytokinaemia [111]. In addition, oestrogen has been suggested to be beneficial in acute central nervous system (CNS) injuries secondary to oxidative and/or excitotoxic stress [112]. For instance, the synthesis of NO, which is known to exert harmful effects on the CNS, is induced via enhanced expression of inducible NOS following CNS injury. E2 and progesterone inhibit the expression of inducible nitric oxide synthase (iNOS) under such conditions [113, 114], and E2 administration downregulates microglial cell-mediated inflammatory responses following trauma-haemorrhage [115]. Additionally, E2 treatment may preserve the integrity of the blood-brain barrier by inhibiting matrix metalloproteinases 2 and 9 activation [116]. Interestingly, females display greater neuronal preservation than males after being subjected to injury such as ischaemia [117].

In a rabbit model of ischaemia-reperfusion injury associated with the spinal cord, testosterone exhibited neuroprotective properties by reducing caspase-3, myeloperoxidase [118] and xanthine oxidase [119] activities, as well as decreasing malondialdehyde levels and increasing catalase concentrations [120]. These results should be interpreted with caution as recent large randomized controlled trials of SSH-based interventions (Progesterone) failed to demonstrate significant benefits following severe traumatic brain injury (TBI) despite promising preclinical studies [121, 122]. Furthermore, a meta-analysis of seven randomized control trials examining progesterone influence following moderate to severe TBI concluded outcomes were not improved compared with placebo [123]. Additionally, elevated systemic levels of estradiol and testosterone following severe TBI have been associated with increased mortality and worse global outcomes for both males and females [119]. Finally, a recently published Cochrane systematic review has graded the quality of current evidence assessing progesterone's influence of TBI as low due to substantial inconsistencies across studies, concluding present evidence do not support the proposal that progesterone reduces mortality or disability in TBI patients nor was it associated with more adverse events, and advised that more precise classification of TBI and optimisation of progesterone dosage and scheduling would benefit future trials [124].

Gender dimorphic renal responses to injury have also been reported. Male mice were more prone to renal injury. Park et al. showed that the presence of testosterone, rather than the absence of oestrogen, inhibited the activation of NOS/Akt/ERK pathway resulting in greater infiltration of leukocytes exacerbating renal cell injury and apoptosis following ischaemic insult [125]. Interestingly, low-dose testosterone demonstrated a renal protective effect following injury through modulating inflammation by enhancing intrarenal inflammatory cytokine production such as IL-10, as well as suppressing renal $\mathrm{T}$ cell infiltration. In contrast, high-dose testosterone displayed pro-inflammatory roles and failed to improve renal function after injury [126]. Furthermore, E2 prevented renal injury by stimulating the Akt pathway and enhancing eNOS phosphorylation [127]. Interestingly, Kasimay et al. investigated gender differences in CRF-induced oxidative multiorgan failure and found that males and oophorectomised females exhibited exaggerated systemic inflammatory responses. E2 treatment significantly improved CRF-induced systemic inflammatory outcomes in both male and female animals by modulating cytokine release and depressing tissue neutrophil infiltration [128].

\section{Burn injury and SSH}

There are several features of the physiological response to burn injury that differ from non-burn injury and require separate consideration in relation to gender dimorphism of outcomes. Thermal injuries are associated with augmented and prolonged hypermetabolic response with resting energy expenditure up to $180 \%$ above normal values, which is more severe than other forms of trauma [129, 130]. This, along with an overwhelming immune-inflammatory response, exerts grievous effects on various body systems characterized by increased oxygen consumption, resting energy expenditure, fat and protein catabolism as well as hyperinsulinemia and enhanced peripheral insulin resistance [131-135]. All of which have a negative impact on organ/tissue function, as well as on tissue mass to the extent that it may lead to complications such as immune dysfunction, delayed wound healing and severe sepsis, as well as growth retardation [130, 136-139]. These hypermetabolic and hyperinflammatory responses have been reported to potentially endure for years post-injury $[138,140]$. 
There is growing evidence that $\mathrm{SSH}$ levels are a major determinant of prognosis following burn injury. An 11year review of data in the UK Greater Manchester region reported that the largest proportion of burn-related deaths $(24.8 \%)$ was among older individuals ( $\geq 75$ years in age) and that the relative risk of mortality was approximately $1.5 \times$ higher in males [141]. An analysis of the international burn injury database for England and Wales (2003-2011) concurred that patients aged 65 years or over suffered longer inhospital length of stay, as well as the highest mortality rates among all other age groups, $19.24 \%$. Interestingly, in this analysis, mortality was generally higher in females than males over the 8year period (1.86\% vs $1.32 \%$ ) and in each individual year examined [142]. This was further supported by Moore et al. who showed that risk of death in women admitted to intensive care post-thermal injury was double when compared with males, OR 2.35 [2]. Gender dimorphism in burn injury thus appears to be the opposite to other forms of injury. This is further supported by Summers et al. who concluded female gender is associated with poorer outcomes following severe thermal injury [143]. A systematic review of the literature published from 1965 till 2012 also identified female gender as a risk factor for hypertrophic scarring in patients who survived their burn injury [144].

There are a limited number of clinical studies investigating the impact of gender on outcomes following thermal injury, though animal studies offer some insight into potential mechanisms that may explain these epidemiological findings. Anathakrishnan et al. described similar responses in rats following burn injury (40\% TBSA) and trauma-haemorrhage, in which both acute lung and intestinal injury were potentiated by oophorectomy and prevented by castration [45]. Wigginton et al. stated that a single intravenous dose of E2 reduced burn injury severity through regulation of the immuno-inflammatory cascade, as well as its anti-oxidant and anti-apoptotic properties [145], and other studies reported estradiol administration, following severe thermal injury, attenuated body mass loss associated with the hypermetabolic response [146]. Gregory et al. suggested that gender dimorphism relating to immune function following severe thermal injury was mediated by oestrogen and its impact on IL-6 production. This study reported that while intact females, at day 10 post-burn, exhibited three times higher levels of plasma IL-6, they also demonstrated suppression of splenocyte proliferation and delayed type hypersensitivity reactions [147]. In contrast, Gatson et al. found administration of E2 after thermal injury attenuated both brain inflammation and apoptotic signalling by down-regulating TNF- $\alpha$, IL- $1 \beta$ and IL- 6 levels within brain tissue [148]. Increasing concentrations of estradiol, through castration or treatments with E2 or anti-androgens, post-burn was also associated with reduced remote organ inflammation [149].

The data concerning the involvement of oestrogens in regulating the response to burn injury is thus mixed even in animal models, with few studies involving human patients. Comparisons of burn injury outcomes in pre- and post-menopausal women or those on HRT would be beneficial in this respect.

\section{Therapeutic potential of SSH \\ Anabolic androgenic steroids (AAS)}

Oxandrolone is an AAS that is derived from testosterone and has a high anabolic:androgenic ratio (10:1) [150]. Oxandrolone has been shown to improve prognosis of various catabolic conditions including severe burns and trauma [151]. It is the only AAS approved by the FDA for weight restitution following extensive surgery and severe trauma.

To date, there has been one multicenter prospective randomized double-blind trial investigating the effects of oxandrolone in adult patients with severe burns. The authors reported significantly shorter lengths of inhospital stay in the oxandrolone group compared to placebo, and this difference was strengthened when deaths were excluded and hospital stay indexed to burn size [152]. A recent meta-analysis of 15 randomized controlled trials reported that oxandrolone use was associated with shorter inhospital length of stay by 3 days, reduced donor site healing time by 4.4 days, and reduced time between surgical procedures by 0.7 days, as well as reduced weight loss by $5 \mathrm{~kg}$ and nitrogen loss by $8.19 \mathrm{~g} /$ day. Moreover, oxandrolone use in the rehabilitation phase was associated with reduced weight loss by $0.86 \mathrm{~kg} /$ week and lean body mass by $5 \%$ as well as gaining $3.99 \%$ and $10.78 \%$ lean body mass following severe thermal injury by 6 and 12 months respectively [153]. Interestingly, oxandrolone and propranolol $(\beta$-blocker used in burns for its anti-catabolic effects) attenuated burn-induced growth arrest in paediatric patients following thermal injury by shortening its duration by 84 days and increased growth rate by $1.7 \mathrm{~cm}$ per year [154]. The use of oxandrolone in paediatric burn patients up to 2 years is associated with greater improvements in bone mineral content, bone mineral density and height velocity [155].

\section{DHEA/DHEAS}

DHEA, a major steroid hormone circulating in plasma, is produced in response to stress and is an intermediate that can be metabolized to both testosterone and oestrogen. It has been reported to exhibit predominantly oestrogenic effects in the male androgenic milieu [156]. In view of the immuno-enhancing properties of oestrogen, studies have investigated the effect of DHEA in animal models of 


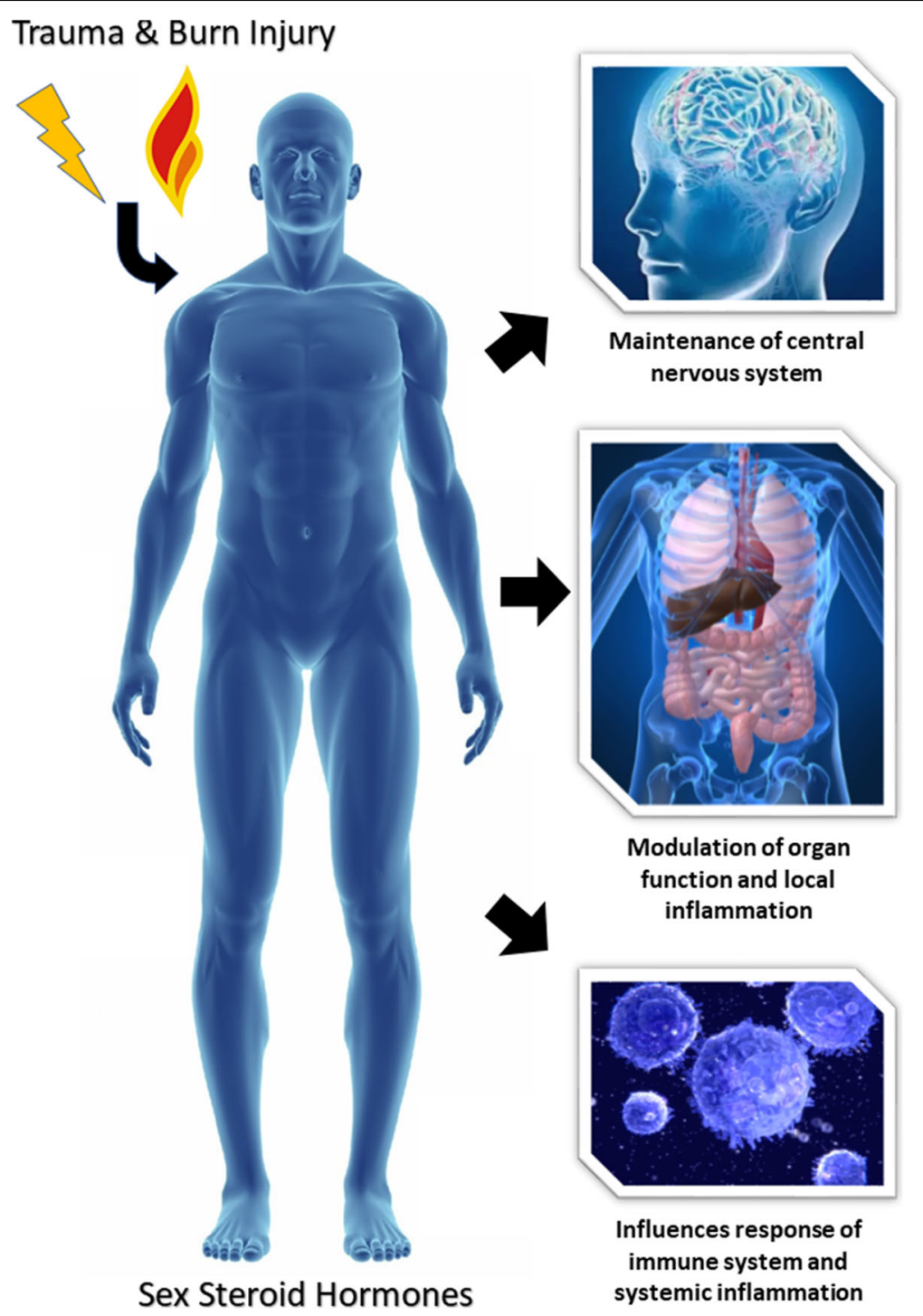

Fig. 1 The influence of SSH on the human body response following injury

trauma-haemorrhage and sepsis. Angele et al. demonstrated that administration of DHEA attenuated depression of splenic and peritoneal macrophage function postinjury and improved mortality rates from subsequent sepsis in a rodent model [157]. Furthermore, DHEA, in post-trauma-haemorrhage, restored splenocyte functions by directly stimulating $\mathrm{T}$ cell functions and preventing increases in serum corticosterone [158]. Interestingly, DHEA has been shown to antagonize the immunosuppressive effects of glucocorticoids such as dexamethasone on lymphocyte proliferation [159], and the sulphated form of DHEA, DHEAS, has been shown to potentiate neutrophil function via direct activation of neutrophil nicotinamide adenine dinucleotide phosphat (NADPH) oxidase and reactive oxygen species (ROS) generation [160].
There are no human trials of DHEA intervention in trauma, and this androgenic hormone has mainly been used in trials for Addison's disease and some chronic inflammatory conditions including rheumatoid arthritis. As the HPA axis is disrupted after trauma, we suggest that supplementation with DHEA may offer a novel, safe and inexpensive route in improving a range of outcomes after injury.

\section{Androgen receptor antagonists}

Several animal studies have indicated that testosterone depletion exerts numerous beneficial effects prior to any systemic insult. Administration of flutamide following trauma-haemorrhage and resuscitation normalized depressed splenic and peritoneal macrophage cytokine 
release [161]. Angele et al. showed that flutamide administration for three consecutive days not only restored diminished immuno-inflammatory responses but also decreased mortality rates associated with subsequent septic challenge [162]. Lin et al. evaluated the use of flutamide in animal models of heatstroke, reporting that flutamide attenuated hypothermia; decreased the number of apoptotic cells within the hypothalamus, spleen, liver and kidney; diminished the plasma index of toxic oxidized radicals such as nitric oxide metabolites; attenuated systemic inflammatory responses including TNF- $\alpha$ and IL- 6 release; and reduced the infiltration of neutrophils into the lungs. All of which contributed to significantly improved mortality rates [163]. Furthermore, flutamide is frequently used in the clinical management of testicular cancer over prolonged periods without major adverse effects. Therefore, short-term use can be considered safe and feasible. Again, there are currently no human studies investigating administration of androgen antagonists following trauma or burn injury.

\section{Conclusions}

The literature contains evidence of gender dimorphism in response to injury, with outcomes better in females than males for most injury types, one possible exception being burn injury. SSH have demonstrated potential to support homeostatic measures following injury by modulating a wide range of processes including inflammation, immune response and organ function (Figure 1). However, at present, most of these data are derived from in vitro or animal-based studies and conclusive clinical trials of interventions with SSH are lacking. Further investigations are merited to ascertain the role of specific $\mathrm{SSH}$ in post-injury pathology as their therapeutic potential may prove invaluable in reducing patient morbidity and mortality in the clinical setting.

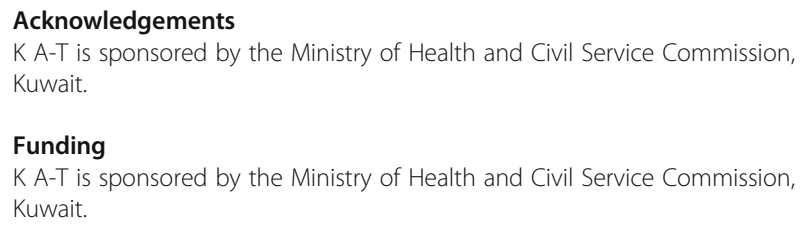

Funding

K A-T is sponsored by the Ministry of Health and Civil Service Commission, Kuwait.

\section{Availability of data and materials}

Not applicable

\section{Authors' contributions}

All authors have written and reviewed the manuscript. All authors read and approved the final manuscript.

Ethics approval and consent to participate

Not applicable

\section{Consent for publication}

Not applicable

\section{Competing interests}

The authors declare no conflicts of interest.

\section{Author details}

${ }^{1}$ Institute of Inflammation and Ageing, Birmingham University Medical School, B15 2TT, Birmingham, UK. ${ }^{2}$ Scar Free Foundation Centre for Burns Research, University Hospital Birmingham Foundation Trust, B15 2WB, Birmingham, UK.

Received: 5 December 2016 Accepted: 19 July 2017

Published online: 14 September 2017

\section{References}

1. Haider AH, Crompton JG, Oyetunij T, Stevens KA, Efron DT, Kieninger AN, et al. Females have fewer complications and lower mortality following trauma than similarly injured males: a risk adjusted analysis of adults in the National Trauma Data Bank. Surgery. 2009;146(2):308-15.

2. Moore EC, Pilcher D, Bailey M, Cleland H. Women are more than twice as likely to die from burns as men in Australia and New Zealand: an unexpected finding of the Burns Evaluation And Mortality (BEAM) Study. J Crit Care. 2014;29(4):594-8.

3. McGowan JE Jr, Barnes MW, Finland M. Bacteremia at Boston City Hospital: Occurrence and mortality during 12 selected years (1935-1972), with special reference to hospital-acquired cases. J Infect Dis. 1975;132(3):316-35.

4. Wearn C, Hardwicke J, Kitsios A, Siddons V, Nightingale P, Moiemen N. Outcomes of burns in the elderly: revised estimates from the Birmingham Burn Centre. Burns. 2015:41(6):1161-8.

5. Lord JM, Midwinter MJ, Chen YF, Belli A, Brohi K, Kovacs EJ, et al. The systemic immune response to trauma: an overview of pathophysiology and treatment. Lancet. 2014;384(9952):1455-65.

6. Sobrino J, Shafi S. Timing and causes of death after injuries. Proc (Baylor Univ Med Cent). 2013;26(2):120-3.

7. Liu T, Xie J, Yang F, Chen JJ, Li ZF, Yi CL, et al. The influence of sex on outcomes in trauma patients: a meta-analysis. Am J Surg. 2015;210(5):911-21.

8. Gannon CJ, Pasquale M, Tracy JK, McCarter RJ, Napolitano LM. Male gender is associated with increased risk for postinjury pneumonia. Shock. 2004; 21(5):410-4.

9. George RL, McGwin G Jr, Windham ST, Melton SM, Metzger J, Chaudry IH, et al. Age-related gender differential in outcome after blunt or penetrating trauma. Shock. 2003;19(1):28-32.

10. Offner PJ, Moore EE, Biffl WL. Male gender is a risk factor for major infections after surgery. Arch Surg. 1999;134(9):935-8. discussion 8-40

11. Schroder J, Kahlke V, Staubach KH, Zabel P, Stuber F. Gender differences in human sepsis. Arch Surg. 1998;133(11):1200-5.

12. Haider AH, Crompton JG, Chang DC, Efron DT, Haut ER, Handly N, et al. Evidence of hormonal basis for improved survival among females with trauma-associated shock: an analysis of the National Trauma Data Bank. J Trauma. 2010;69(3):537-40.

13. Trentzsch $H$, Lefering R, Nienaber $U$, Kraft R, Faist E, Piltz $S$. The role of biological sex in severely traumatized patients on outcomes: a matched-pair analysis. Ann Surg. 2015;261(4):774-80.

14. McKinley BA, Kozar RA, Cocanour CS, Valdivia A, Sailors RM, Ware DN, et al. Standardized trauma resuscitation: female hearts respond better. Arch Surg. 2002;137(5):578-83. discussion 83-4

15. Deitch EA, Livingston DH, Lavery RF, Monaghan SF, Bongu A, Machiedo GW. Hormonally active women tolerate shock-trauma better than do men: a prospective study of over 4000 trauma patients. Ann Surg. 2007;246(3):447-53. discussion 53-5

16. Rappold JF, Coimbra R, Hoyt DB, Potenza BM, Fortlage D, Holbrook T, et al. Female gender does not protect blunt trauma patients from complications and mortality. J Trauma. 2002;53(3):436-41. discussion 41

17. Bowles BJ, Roth B, Demetriades D. Sexual dimorphism in trauma? A retrospective evaluation of outcome. Injury. 2003;34(1):27-31.

18. Coimbra R, Hoyt DB, Potenza BM, Fortlage D, Hollingsworth-Fridlund P. Does sexual dimorphism influence outcome of traumatic brain injury patients? The answer is no! J Trauma. 2003;54(4):689-700.

19. Gannon CJ, Napolitano LM, Pasquale M, Tracy JK, McCarter RJ. A statewide population-based study of gender differences in trauma: validation of a prior single-institution study. J Am Coll Surg. 2002;195(1):11-8.

20. Harbrecht BG, Peitzman AB, Rivera L, Heil B, Croce M, Morris JA Jr, et al. Contribution of age and gender to outcome of blunt splenic injury in adults: multicenter study of the eastern association for the surgery of trauma. J Trauma. 2001;51(5):887-95. 
21. Holbrook TL, Hoyt DB, Anderson JP. The importance of gender on outcome after major trauma: functional and psychologic outcomes in women versus men. J Trauma. 2001;50(2):270-3.

22. Napolitano LM, Greco ME, Rodriguez A, Kufera JA, West RS, Scalea TM. Gender differences in adverse outcomes after blunt trauma. J Trauma. 2001:50(2):274-80.

23. Klein SL. Hormonal and immunological mechanisms mediating sex differences in parasite infection. Parasite Immunol. 2004;26(6-7):247-64.

24. Baue AE. MOF, MODS, and SIRS: what is in a name or an acronym? Shock 2006;26(5):438-49.

25. Murphy TJ, Paterson HM, Kriynovich S, Zang Y, Kurt-Jones EA, Mannick JA, et al. Linking the "two-hit" response following injury to enhanced TLR4 reactivity. J Leukoc Biol. 2005;77(1):16-23.

26. Murphy TJ, Paterson HM, Mannick JA, Lederer JA. Injury, sepsis, and the regulation of Toll-like receptor responses. J Leukoc Biol. 2004;75(3):400-7.

27. Ulloa L, Tracey KJ. The "cytokine profile": a code for sepsis. Trends Mol Med. 2005:11(2):56-63.

28. Wichmann MW, Muller C, Meyer G, Adam M, Angele MK, Eisenmenger SJ, et al. Different immune responses to abdominal surgery in men and women. Langenbeck's Arch Surg. 2003;387(11-12):397-401.

29. Majetschak M, Christensen B, Obertacke U, Waydhas C, Schindler AE, Nast-Kolb D, et al. Sex differences in posttraumatic cytokine release of endotoxin-stimulated whole blood: relationship to the development of severe sepsis. J Trauma. 2000;48(5):832-9. discussion 9-40

30. Oberholzer A, Keel M, Zellweger R, Steckholzer U, Trentz O, Ertel W. Incidence of septic complications and multiple organ failure in severely injured patients is sex specific. J Trauma. 2000:48(5):932-7.

31. D'Agostino P, Milano S, Barbera C, Di Bella G, La Rosa M, Ferlazzo V, et al. Sex hormones modulate inflammatory mediators produced by macrophages. Ann N Y Acad Sci. 1999;876:426-9.

32. Hou J, Zheng WF. Effect of sex hormones on NK and ADCC activity of mice. Int J Immunopharmacol. 1988;10(1):15-22

33. McKay LI, Cidlowski JA. Molecular control of immune/inflammatory responses: interactions between nuclear factor-kappa B and steroid receptor-signaling pathways. Endocr Rev. 1999;20(4):435-59.

34. Rettew JA, Huet-Hudson YM, Marriott I. Testosterone reduces macrophage expression in the mouse of toll-like receptor 4, a trigger for inflammation and innate immunity. Biol Reprod. 2008;78(3):432-7.

35. Su L, Sun Y, Ma F, Lu P, Huang H, Zhou J. Progesterone inhibits Toll-like receptor 4-mediated innate immune response in macrophages by suppressing NF-kappaB activation and enhancing SOCS1 expression. Immunol Lett. 2009;125(2):151-5.

36. Furukawa K, Itoh K, Okamura K, Kumagai K, Suzuki M. Changes in Nk CellActivity during the Estrous-Cycle and Pregnancy in Mice. J Reprod Immunol. 1984;6(6):353-63.

37. Lu FX, Abel K, Ma Z, Rourke T, Lu D, Torten J, et al. The strength of B cell immunity in female rhesus macaques is controlled by CD8+ T cells under the influence of ovarian steroid hormones. Clin Exp Immunol. 2002;128(1):10-20.

38. Miller L, Hunt JS. Sex steroid hormones and macrophage function. Life Sci. 1996;59(1):1-14

39. Savita RU. Sex steroid hormones modulate the activation of murine peritoneal macrophages: Receptor mediated modulation. Comp Biochem Physiol C. 1998;119(2):199-204.

40. Robinson DP, Klein SL. Pregnancy and pregnancy-associated hormones alter immune responses and disease pathogenesis. Horm Behav. 2012;62(3):263-71.

41. Sorachi K, Kumagai S, Sugita M, Yodoi J, Imura H. Enhancing effect of 17 beta-estradiol on human NK cell activity. Immunol Lett. 1993;36(1):31-5.

42. Kahlke V, Angele MK, Ayala A, Schwacha MG, Cioffi WG, Bland Kl, et al. Immune dysfunction following trauma-haemorrhage: influence of gender and age. Cytokine. 2000;12(1):69-77.

43. Straub $\mathrm{RH}$. The complex role of estrogens in inflammation. Endocr Rev. 2007;28(5):521-74

44. Vegeto E, Pollio G, Pellicciari C, Maggi A. Estrogen and progesterone induction of survival of monoblastoid cells undergoing TNF-alpha-induced apoptosis. FASEB J. 1999;13(8):793-803.

45. Ananthakrishnan P, Cohen DB, Xu DZ, Lu Q, Feketeova E, Deitch EA. Sex hormones modulate distant organ injury in both a trauma/hemorrhagic shock model and a burn model. Surgery. 2005;137(1):56-65.

46. Angele MK, Schwacha MG, Ayala A, Chaudry $\mathbb{H}$. Effect of gender and sex hormones on immune responses following shock. Shock. 2000;14(2):81-90.
47. Angele MK, Ayala A, Cioffi WG, Bland Kl, Chaudry IH. Testosterone: the culprit for producing splenocyte immune depression after trauma hemorrhage. Am J Phys. 1998;274(6 Pt 1):C1530-6.

48. Angele MK, Ayala A, Monfils BA, Cioffi WG, Bland Kl, Chaudry IH. Testosterone and/or low estradiol: normally required but harmful immunologically for males after trauma-hemorrhage. J Trauma. 1998;44(1):78-85.

49. Angele MK, Knoferl MW, Ayala A, Bland Kl, Chaudry IH. Testosterone and estrogen differently effect Th1 and Th2 cytokine release following traumahaemorrhage. Cytokine. 2001;16(1):22-30.

50. Wichmann MW, Ayala A, Chaudry $\mathbb{H}$. Male sex steroids are responsible for depressing macrophage immune function after trauma-hemorrhage. Am J Phys. 1997;273(4 Pt 1):C1335-40.

51. Wichmann MW, Zellweger R, DeMaso CM, Ayala A, Chaudry IH. Mechanism of immunosuppression in males following trauma-hemorrhage. Critical role of testosterone. Arch Surg. 1996;131(11):1186-91. discussion 91-2

52. Knoferl MW, Angele MK, Schwacha MG, Bland Kl, Chaudry IH. Preservation of splenic immune functions by female sex hormones after traumahemorrhage. Crit Care Med. 2002;30(4):888-93.

53. Knoferl MW, Diodato MD, Angele MK, Ayala A, Cioffi WG, Bland Kl, et al. Do female sex steroids adversely or beneficially affect the depressed immune responses in males after trauma-hemorrhage? Arch Surg. 2000;135(4):425-33.

54. Knoferl MW, Jarrar D, Angele MK, Ayala A, Schwacha MG, Bland Kl, et al. 17 beta-Estradiol normalizes immune responses in ovariectomized females after trauma-hemorrhage. Am J Phys Cell Physiol. 2001;281(4):C1131-8.

55. Dienstknecht T, Schwacha MG, Kang SC, Rue LW, Bland Kl, Chaudry IH. Sex steroid-mediated regulation of macrophage/monocyte function in a two-hit model of trauma-hemorrhage and sepsis. Cytokine. 2004;25(3):110-8.

56. Mayr S, Walz CR, Angele P, Hernandez-Richter T, Chaudry IH, Loehe F, et al. Castration prevents suppression of MHC class II (la) expression on macrophages after trauma-hemorrhage. J Appl Physiol (1985). 2006:101(2):448-53.

57. Hildebrand F, Hubbard WJ, Choudhry MA, Thobe BM, Pape HC, Chaudry IH. Are the protective effects of 17 beta-estradiol on splenic macrophages and splenocytes after trauma-hemorrhage mediated via estrogen-receptor (ER)-alpha or ER-beta? J Leukoc Biol. 2006:79(6):1173-80.

58. Samy TS, Zheng R, Matsutani T, Rue LW 3rd, Bland Kl, Chaudry $I H$. Mechanism for normal splenic T lymphocyte functions in proestrus females after trauma: enhanced local synthesis of 17beta-estradiol. Am J Phys Cell Physiol. 2003;285(1):C139-49.

59. Suzuki T, Shimizu T, Yu HP, Hsieh YC, Choudhry MA, Bland Kl, et al. Estrogen receptor-alpha predominantly mediates the salutary effects of 17 betaestradiol on splenic macrophages following trauma-hemorrhage. Am J Phys Cell Physiol. 2007;293(3):C978-84.

60. Kawasaki T, Choudhry MA, Suzuki T, Schwacha MG, Bland Kl, Chaudry IH. 17beta-Estradiol's salutary effects on splenic dendritic cell functions following trauma-hemorrhage are mediated via estrogen receptor-alpha. Mol Immunol. 2008:45(2):376-85

61. Trentzsch $\mathrm{H}$, Nienaber $U$, Behnke $M$, Lefering R, Piltz S. Female sex protects from organ failure and sepsis after major trauma haemorrhage. Injury. 2014:45(Suppl 3):S20-8.

62. Zolin SJ, Vodovotz Y, Forsythe RM, Rosengart MR, Namas R, Brown JB, et al. The early evolving sex hormone environment is associated with significant outcome and inflammatory response differences after injury. J Trauma Acute Care Surg. 2015:78(3):451-7. discussion 7-8

63. Gee AC, Sawai RS, Differding J, Muller P, Underwood S, Schreiber MA. The influence of sex hormones on coagulation and inflammation in the trauma patient. Shock. 2008;29(3):334-41.

64. Lopez MC, Efron PA, Ozrazgat-Baslanti T, Zhang J, Cuschieri J, Maier RV, et al. Sex-based differences in the genomic response, innate immunity, organ dysfunction, and clinical outcomes after severe blunt traumatic injury and hemorrhagic shock. J Trauma Acute Care Surg. 2016;81(3):478-85.

65. Wang P, Ba ZF, Burkhardt J, Chaudry $\mathbb{H}$. Trauma-hemorrhage and resuscitation in the mouse: effects on cardiac output and organ blood flow. Am J Phys. 1993;264(4 Pt 2):H1166-73.

66. Wang $P$, Hauptman JG, Chaudry $\mathbb{I H}$. Hemorrhage produces depression in microvascular blood flow which persists despite fluid resuscitation. Circ Shock. 1990:32(4):307-18.

67. Remmers DE, Cioffi WG, Bland Kl, Wang P, Angele MK, Chaudry $\mathbb{H}_{\text {. }}$ Testosterone: the crucial hormone responsible for depressing myocardial function in males after trauma-hemorrhage. Ann Surg. 1998;227(6):790-9. 
68. Remmers DE, Wang P, Cioffi WG, Bland Kl, Chaudry IH. Testosterone receptor blockade after trauma-hemorrhage improves cardiac and hepatic functions in males. Am J Phys. 1997;273(6 Pt 2):H2919-25.

69. Kuebler JF, Jarrar D, Bland Kl, Rue L 3rd, Wang P, Chaudry $H$. Progesterone administration after trauma and hemorrhagic shock improves cardiovascular responses. Crit Care Med. 2003;31(6):1786-93.

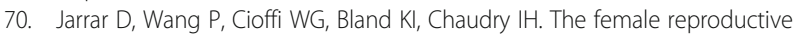
cycle is an important variable in the response to trauma-hemorrhage. Am J Physiol Heart Circ Physiol. 2000;279(3):H1015-21.

71. Mizushima Y, Wang P, Jarrar D, Cioffi WG, Bland KI, Chaudry IH. Estradiol administration after trauma-hemorrhage improves cardiovascular and hepatocellular functions in male animals. Ann Surg. 2000;232(5):673-9.

72. Nickel EA, Hsieh $\mathrm{CH}$, Chen JG, Schwacha MG, Chaudry IH. Estrogen suppresses cardiac IL-6 after trauma-hemorrhage via a hypoxia-inducible factor 1 alpha-mediated pathway. Shock. 2009;31(4):354-8.

73. Yang S, Zheng R, Hu S, Ma Y, Choudhry MA, Messina JL, et al. Mechanism of cardiac depression after trauma-hemorrhage: increased cardiomyocyte IL-6 and effect of sex steroids on IL-6 regulation and cardiac function. Am J Physiol Heart Circ Physiol. 2004;287(5):H2183-91.

74. Szalay L, Shimizu T, Schwacha MG, Choudhry MA, Rue LW 3rd, Bland KI, et al. Mechanism of salutary effects of estradiol on organ function after trauma-hemorrhage: upregulation of heme oxygenase. Am J Physiol Heart Circ Physiol. 2005;289(1):H92-8.

75. Hsu JT, Hsieh YC, Kan WH, Chen JG, Choudhry MA, Schwacha MG, et al. Role of p38 mitogen-activated protein kinase pathway in estrogenmediated cardioprotection following trauma-hemorrhage. Am J Physiol Heart Circ Physiol. 2007;292(6):H2982-7.

76. Kan WH, Hsu JT, Ba ZF, Schwacha MG, Chen J, Choudhry MA, et al. p38 MAPK-dependent eNOS upregulation is critical for 17beta-estradiolmediated cardioprotection following trauma-hemorrhage. Am J Physiol Heart Circ Physiol. 2008;294(6):H2627-36.

77. Hsu JT, Kan WH, Hsieh CH, Choudhry MA, Bland Kl, Chaudry IH. Mechanism of salutary effects of estrogen on cardiac function following traumahemorrhage: Akt-dependent HO-1 up-regulation. Crit Care Med. 2009;37(8):2338-44.

78. Liu CJ, Lo JF, Kuo CH, Chu CH, Chen LM, Tsai FJ, et al. Akt mediates 17betaestradiol and/or estrogen receptor-alpha inhibition of LPS-induced tumor necresis factor-alpha expression and myocardial cell apoptosis by suppressing the JNK1/2-NFkappaB pathway. J Cell Mol Med. 2009;13(9b):3655-67.

79. Yu HP, Hsieh YC, Suzuki T, Choudhry MA, Schwacha MG, Bland Kl, et al. The PI3K/Akt pathway mediates the nongenomic cardioprotective effects of estrogen following trauma-hemorrhage. Ann Surg. 2007;245(6):971-7.

80. Wang M, Wang Y, Abarbanell A, Tan J, Weil B, Herrmann J, et al. Both Endogenous And Exogenous Testosterone Decrease Myocardial Stat3 Activation And Socs3 Expression Following Acute Ischemia And Reperfusion. Surgery. 2009;146(2):138-44.

81. Huang C, Gu H, Zhang W, Herrmann JL, Wang M. Testosterone-downregulated $A$ kt pathway during cardiac ischemia/reperfusion: a mechanism involving BAD, BCl-2 and FOXO3a. J Surg Res. 2010;164(1):e1-11.

82. Pongkan W, Chattipakorn SC, Chattipakorn N. Roles of Testosterone Replacement in Cardiac Ischemia-Reperfusion Injury. J Cardiovasc Pharmacol Ther. 2016;21(1):27-43.

83. Koh KK, Mincemoyer R, Bui MN, Csako G, Pucino F, Guetta V, et al. Effects of Hormone-Replacement Therapy on Fibrinolysis in Postmenopausal Women. N Engl J Med. 1997;336(10):683-91.

84. Harnett MJ, Bhavani-Shankar K, Datta S, Tsen LC. In vitro fertilization-induced alterations in coagulation and fibrinolysis as measured by thromboelastography. Anesth Analg. 2002;95(4):1063-6. table of contents

85. Schreiber MA, Differding J, Thorborg P, Mayberry JC, Mullins RJ. Hypercoagulability is most prevalent early after injury and in female patients. J Trauma. 2005:58(3):475-80. discussion 80-1

86. Brown JB, Cohen MJ, Minei JP, Maier RV, West MA, Billiar TR, et al. Characterization of acute coagulopathy and sexual dimorphism after injury: females and coagulopathy just do not mix. J Trauma Acute Care Surg. 2012; 73(6):1395-400.

87. Erikoglu M, Sahin M, Ozer S, Avunduk MC. Effects of gender on the severity of sepsis. Surg Today. 2005;35(6):467-72.

88. Eckhoff DE, Bilbao G, Frenette L, Thompson JA, Contreras JL. 17-Betaestradiol protects the liver against warm ischemia/reperfusion injury and is associated with increased serum nitric oxide and decreased tumor necrosis factor-alpha. Surgery. 2002;132(2):302-9.
89. Hsieh CH, Nickel EA, Chen J, Schwacha MG, Choudhry MA, Bland Kl, et al. Mechanism of the salutary effects of estrogen on kupffer cell phagocytic capacity following trauma-hemorrhage: pivotal role of Akt activation. J Immunol. 2009;182(7):4406-14.

90. Hsieh YC, Frink M, Thobe BM, Hsu JT, Choudhry MA, Schwacha MG, et al. 17Beta-estradiol downregulates Kupffer cell TLR4-dependent p38 MAPK pathway and normalizes inflammatory cytokine production following trauma-hemorrhage. Mol Immunol. 2007;44(9):2165-72.

91. Yokoyama Y, Kuebler JF, Matsutani T, Schwacha MG, Bland Kl, Chaudry $\mathbb{H}$. Mechanism of the salutary effects of 17beta-estradiol following traumahemorrhage: direct downregulation of Kupffer cell proinflammatory cytokine production. Cytokine. 2003;21(2):91-7.

92. Hsieh YC, Frink M, Kawasaki T, Thobe BM, Choudhry MA, Schwacha MG, et al. Downregulation of TLR4-dependent ATP production is critical for estrogen-mediated immunoprotection in Kupffer cells following traumahemorrhage. J Cell Physiol. 2007;211(2):364-70.

93. Hsu JT, Kan WH, Hsieh CH, Choudhry MA, Schwacha MG, Bland Kl, et al. Mechanism of estrogen-mediated attenuation of hepatic injury following trauma-hemorrhage: Akt-dependent HO-1 up-regulation. J Leukoc Biol. 2007:82(4):1019-26.

94. Yang S, Hu S, Chen J, Choudhry MA, Rue LW 3rd, Bland Kl, et al. Mechanism of hepatoprotection in proestrus female rats following trauma-hemorrhage: heme oxygenase-1-derived normalization of hepatic inflammatory responses. J Leukoc Biol. 2009;85(6):1015-26.

95. Suzuki T, Shimizu T, Yu HP, Hsieh YC, Choudhry MA, Bland Kl, et al. 17 betaestradiol administration following trauma-hemorrhage prevents the increase in Kupffer cell cytokine production and MAPK activation predominately via estrogen receptor-alpha. Surgery. 2006;140(2):141-8.

96. Han JE, Jones JL, Tangpricha V, Brown MA, Brown LA, Hao L, et al. High Dose Vitamin D Administration in Ventilated Intensive Care Unit Patients: A Pilot Double Blind Randomized Controlled Trial. J Clin Transl Endocrinol. 2016;4:59-65.

97. Hsieh YC, Yu HP, Frink M, Suzuki T, Choudhry MA, Schwacha MG, et al. G protein-coupled receptor 30-dependent protein kinase A pathway is critical in nongenomic effects of estrogen in attenuating liver injury after traumahemorrhage. Am J Pathol. 2007;170(4):1210-8.

98. Sheth SU, Palange D, Xu DZ, Wei D, Feketeova E, Lu Q, et al. Testosterone depletion or blockade in male rats protects against trauma hemorrhagic shock-induced distant organ injury by limiting gut injury and subsequent production of biologically active mesenteric lymph. J Trauma. 2011;71(6): 1652-8.

99. Deitch EA, Senthil M, Brown M, Caputo F, Watkins A, Anjaria D, et al. Trauma-shock-induced gut injury and the production of biologically active intestinal lymph is abrogated by castration in a large animal porcine model. Shock. 2008;30(2):135-41.

100. Ba ZF, Shimizu T, Szalay L, Bland Kl, Chaudry $I H$. Gender differences in small intestinal perfusion following trauma hemorrhage: the role of endothelin-1. Am J Physiol Gastrointest Liver Physiol. 2005;288(5):G860-5.

101. Yokoyama Y, Toth B, Kitchens WC, Schwacha MG, Rue LW 3rd, Bland Kl, et al. Estradiol's effect on portal response to endothelin-1 after traumahemorrhage. J Surg Res. 2004;121(1):25-30.

102. Hsu JT, Kan WH, Hsieh CH, Choudhry MA, Schwacha MG, Bland Kl, et al. Mechanism of estrogen-mediated intestinal protection following traumahemorrhage: p38 MAPK-dependent upregulation of HO-1. Am J Phys Regul Integr Comp Phys. 2008;294(6):R1825-31.

103. Yu HP, Hsieh YC, Suzuki T, Choudhry MA, Schwacha MG, Bland Kl, et al. Mechanism of the nongenomic effects of estrogen on intestinal myeloperoxidase activity following trauma-hemorrhage: up-regulation of the PI-3KJAkt pathway. J Leukoc Biol. 2007;82(3):774-80.

104. Shimizu T, Yu HP, Hsieh YC, Choudhry MA, Suzuki T, Bland Kl, et al. Flutamide attenuates pro-inflammatory cytokine production and hepatic injury following trauma-hemorrhage via estrogen receptor-related pathway. Ann Surg. 2007;245(2):297-304.

105. Caruso JM, Xu DZ, Lu Q, Dayal SD, Deitch EA. The female gender protects against pulmonary injury after trauma hemorrhagic shock. Surg Infect. 2001;2(3):231-40.

106. Tominaga K, Kataoka Y, Sendo T, Furuta W, Niizeki M, Oishi AR. Contrast medium-induced pulmonary vascular hyperpermeability is aggravated in a rat climacterium model. Investig Radiol. 2001;36(3):131-5.

107. Frink $M$, Thobe BM, Hsieh YC, Choudhry MA, Schwacha MG, Bland Kl, et al. 17beta-Estradiol inhibits keratinocyte-derived chemokine production 
following trauma-hemorrhage. Am J Phys Lung Cell Mol Phys. 2007;292(2): L585-91.

108. Hsieh YC, Frink M, Hsieh CH, Choudhry MA, Schwacha MG, Bland Kl, et al. Downregulation of migration inhibitory factor is critical for estrogenmediated attenuation of lung tissue damage following trauma-hemorrhage. Am J Phys Lung Cell Mol Phys. 2007;292(5):L1227-32.

109. Hsu JT, Kan WH, Hsieh CH, Choudhry MA, Bland Kl, Chaudry IH. Role of extracellular signal-regulated protein kinase (ERK) in 17beta-estradiolmediated attenuation of lung injury after trauma-hemorrhage. Surgery. 2009;145(2):226-34.

110. Kan WH, Hsu JT, Schwacha MG, Choudhry MA, Bland KI, Chaudry IH. Estrogen ameliorates trauma-hemorrhage-induced lung injury via endothelial nitric oxide synthase-dependent activation of protein kinase G Ann Surg. 2008;248(2):294-302.

111. Chisari AN, Gaillard RC, Giovambattista A, Voirol MJ, Piermaria J, Spinedi E. Sexual dimorphism in the hypothalamo-pituitary-adrenal (HPA) axis and TNFalpha responses to phospholipase A2-related neurotoxin (from crotalus durissus terrifcus) challenge. J Endocrinol Investig. 2000;23(7):440-8.

112. Regan RF, Guo Y. Estrogens attenuate neuronal injury due to hemoglobin, chemical hypoxia, and excitatory amino acids in murine cortical cultures. Brain Res. 1997;764(1-2):133-40

113. Coughlan T, Gibson C, Murphy S. Modulatory effects of progesterone on inducible nitric oxide synthase expression in vivo and in vitro. J Neurochem. 2005;93(4):932-42.

114. Lin CL, Shih HC, Dumont AS, Kassell NF, Lieu AS, Su YF, et al. The effect of 17beta-estradiol in attenuating experimental subarachnoid hemorrhageinduced cerebral vasospasm. J Neurosurg. 2006;104(2):298-304.

115. Akabori H, Moeinpour F, Bland Kl, Chaudry $\mathrm{H}$. Mechanism of the antiinflammatory effect Of 17beta-estradiol on brain following traumahemorrhage. Shock. 2010;33(1):43-8.

116. Liu R, Wen Y, Perez E, Wang X, Day AL, Simpkins JW, et al. 17beta-Estradio attenuates blood-brain barrier disruption induced by cerebral ischemiareperfusion injury in female rats. Brain Res. 2005;1060(1-2):55-61.

117. Hall ED, Pazara KE, Linseman KL. Sex differences in postischemic neuronal necrosis in gerbils. J Cereb Blood Flow Metab. 1991;11(2):292-8.

118. Fantappie MR, Galina A, Luis de Mendonca R, Furtado DR, Secor WE, Colley DG, et al. Molecular characterisation of a NADH ubiquinone oxidoreductase subunit 5 from Schistosoma mansoni and inhibition of mitochondrial respiratory chain function by testosterone. Mol Cell Biochem. 1999;202(1-2):149-58.

119. Wagner AK, McCullough EH, Niyonkuru C, Ozawa H, Loucks TL, Dobos JA, et al. Acute serum hormone levels: characterization and prognosis after severe traumatic brain injury. J Neurotrauma. 2011;28(6):871-88.

120. Gurer B, Kertmen H, Kasim E, Yilmaz ER, Kanat BH, Sargon MF, et al. Neuroprotective effects of testosterone on ischemia/reperfusion injury of the rabbit spinal cord. Injury. 2015;46(2):240-8.

121. Skolnick BE, Maas Al, Narayan RK, van der Hoop RG, MacAllister T, Ward JD, et al. A clinical trial of progesterone for severe traumatic brain injury. N Engl J Med. 2014;371(26):2467-76.

122. Wright DW, Yeatts SD, Silbergleit R, Palesch YY, Hertzberg VS, Frankel M, et al. Very early administration of progesterone for acute traumatic brain injury. N Engl J Med. 2014;371(26):2457-66.

123. Lin C, He H, Li Z, Liu Y, Chao H, Ji J, et al. Efficacy of progesterone for moderate to severe traumatic brain injury: a meta-analysis of randomized clinical trials. Sci Rep. 2015;5:13442.

124. Ma J, Huang S, Qin S, You C, Zeng Y. Progesterone for acute traumatic brain injury. Cochrane Database Syst Rev. 2016;12:Cd008409.

125. Park KM, Kim Jl, Ahn Y, Bonventre AJ, Bonventre JV. Testosterone is responsible for enhanced susceptibility of males to ischemic renal injury. J Biol Chem. 2004;279(50):52282-92.

126. Patil CN, Wallace K, LaMarca BD, Moulana M, Lopez-Ruiz A, Soljancic A, et al. Low-dose testosterone protects against renal ischemia-reperfusion injury by increasing renal IL-10-to-TNF-alpha ratio and attenuating T-cell infiltration. Am J Physiol Ren Physiol. 2016;311(2):F395-403.

127. Satake A, Takaoka M, Nishikawa M, Yuba M, Shibata Y, Okumura K, et al. Protective effect of 17beta-estradiol on ischemic acute renal failure through the PI3K/Akt/eNOS pathway. Kidney Int. 2008;73(3):308-17.

128. Kasimay O, Sener G, Cakir B, Yuksel M, Cetinel S, Contuk G, et al. Estrogen protects against oxidative multiorgan damage in rats with chronic renal failure. Ren Fail. 2009;31(8):711-25.
129. Pereira CT, Murphy KD, Herndon DN. Altering metabolism. J Burn Care Rehabil. 2005;26(3):194-9.

130. Jeschke MG, Chinkes DL, Finnerty CC, Kulp G, Suman OE, Norbury WB, et al. Pathophysiologic response to severe burn injury. Ann Surg. 2008;248(3):387-401.

131. Milner EA, Cioffi WG, Mason AD, McManus WF, Pruitt BA Jr. A longitudinal study of resting energy expenditure in thermally injured patients. J Trauma. 1994;37(2):167-70.

132. Wolfe RR. Metabolic response to burn injury: nutritional implications. Keio J Med. 1993:42(1):1-8.

133. Tredget EE, Yu YM. The metabolic effects of thermal injury. World I Surg. 1992;16(1):68-79.

134. Hampson P, Dinsdale RJ, Wearn CM, Bamford AL, Bishop JRB, Hazeldine J, et al. Neutrophil Dysfunction, Immature Granulocytes, and Cell-free DNA are Early Biomarkers of Sepsis in Burn-injured Patients: A Prospective Observational Cohort Study. Ann Surg. 2017;265(6):1241-9.

135. Porter C, Tompkins RG, Finnerty CC, Sidossis LS, Suman OE, Herndon DN. The metabolic stress response to burn trauma: current understanding and therapies. Lancet. 2016;388(10052):1417-26.

136. Chao T, Herndon DN, Porter C, Chondronikola M, Chaidemenou A, Abdelrahman DR, et al. Skeletal Muscle Protein Breakdown Remains Elevated In Pediatric Burn Survivors Up To One-Year Post-Injury. Shock. 2015;44(5):397-401.

137. Klein GL, Herndon DN, Langman CB, Rutan TC, Young WE, Pembleton G, et al. Long-term reduction in bone mass after severe burn injury in children. J Pediatr. 1995;126(2):252-6.

138. Przkora R, Barrow RE, Jeschke MG, Suman OE, Celis M, Sanford AP, et al. Body composition changes with time in pediatric burn patients. J Trauma. 2006;60(5):968-71. discussion 71

139. Rutan RL, Herndon DN. Growth delay in postburn pediatric patients. Arch Surg. 1990;125(3):392-5.

140. Jeschke MG, Gauglitz GG, Kulp GA, Finnerty CC, Williams FN, Kraft R, et al. Long-term persistance of the pathophysiologic response to severe burn injury. PLoS One. 2011;6(7):e21245.

141. Hussain A, Dunn K. Burn related mortality in Greater Manchester: 11-year review of Regional Coronial Department Data. Burns. 2015:41(2):225-34.

142. Stylianou N, Buchan I, Dunn KW. A review of the international Burn Injury Database (iBID) for England and Wales: descriptive analysis of burn injuries 2003-2011. BMJ Open. 2015;5(2):e006184.

143. Summers J, Ziembicki JA, Corcos AC, Peitzman AB, Billiar TR, Sperry JL. Characterization of sex dimorphism following severe thermal injury. J Burn Care Res. 2014;35(6):484-90.

144. Lawrence JW, Mason ST, Schomer K, Klein MB. Epidemiology and impact of scarring after burn injury: a systematic review of the literature. J Burn Care Res. 2012;33(1):136-46.

145. Wigginton JG, Pepe PE, Idris AH. Rationale for routine and immediate administration of intravenous estrogen for all critically ill and injured patients. Crit Care Med. 2010;38(10 Suppl):S620-9.

146. Abdelfattah KR, Gatson JW, Maass DL, Wolf SE, Minei JP, Wigginton JG 17beta-Estradiol reappropriates mass lost to the hypermetabolic state in thermally injured rats. J Surg Res. 2013;181(1):136-41.

147. Gregory MS, Duffner LA, Faunce DE, Kovacs EJ. Estrogen mediates the sex difference in post-burn immunosuppression. J Endocrinol. 2000;164(2):129-38.

148. Gatson JW, Maass DL, Simpkins JW, Idris AH, Minei JP, Wigginton JG. Estrogen treatment following severe burn injury reduces brain inflammation and apoptotic signaling. J Neuroinflammation. 2009;6:30.

149. Ozveri ES, Bozkurt A, Haklar G, Cetinel S, Arbak S, Yegen C, et al. Estrogens ameliorate remote organ inflammation induced by burn injury in rats. Inflamm Res. 2001;50(12):585-91.

150. Kuhn CM. Anabolic steroids. Recent Prog Horm Res. 2002;57:411-34.

151. Orr R, Fiatarone SM. The anabolic androgenic steroid oxandrolone in the treatment of wasting and catabolic disorders: review of efficacy and safety. Drugs. 2004;64(7):725-50.

152. Wolf SE, Edelman LS, Kemalyan N, Donison L, Cross J, Underwood M, et al. Effects of oxandrolone on outcome measures in the severely burned: a multicenter prospective randomized double-blind trial. J Burn Care Res. 2006:27(2):131-9. discussion 40-1

153. Li H, Guo Y, Yang Z, Roy M, Guo Q. The efficacy and safety of oxandrolone treatment for patients with severe burns: A systematic review and meta-analysis. Burns. 2016;42(4):717-27. 
154. Herndon DN, Voigt CD, Capek KD, Wurzer P, Guillory A, Kline A, et al. Reversal of Growth Arrest With the Combined Administration of Oxandrolone and Propranolol in Severely Burned Children. Ann Surg. 2016;264(3):421-8.

155. Reeves PT, Herndon DN, Tanksley JD, Jennings K, Klein GL, Mlcak RP, et al. Five-Year Outcomes After Long-Term Oxandrolone Administration In Severely Burned Children: A Randomized Clinical Trial. Shock. 2016:45(4):367-74.

156. Ebeling P, Koivisto VA. Physiological importance of dehydroepiandrosterone. Lancet. 1994;343(8911):1479-81.

157. Angele MK, Catania RA, Ayala A, Cioffi WG, Bland Kl, Chaudry IH Dehydroepiandrosterone: an inexpensive steroid hormone that decreases the mortality due to sepsis following trauma-induced hemorrhage. Arch Surg. 1998;133(12):1281-8.

158. Catania RA, Angele MK, Ayala A, Cioffi WG, Bland Kl, Chaudry IH. Dehydroepiandrosterone restores immune function following traumahaemorrhage by a direct effect on T lymphocytes. Cytokine. 1999;11(6):443-50.

159. Blauer KL, Poth M, Rogers WM, Bernton EW. Dehydroepiandrosterone antagonizes the suppressive effects of dexamethasone on lymphocyte proliferation. Endocrinology. 1991;129(6):3174-9.

160. Radford DJ, Wang K, McNelis JC, Taylor AE, Hechenberger G, Hofmann J, et al. Dehydroepiandrosterone sulfate directly activates protein kinase C-beta to increase human neutrophil superoxide generation. Mol Endocrinol. 2010;24(4):813-21.

161. Wichmann MW, Angele MK, Ayala A, Cioffi WG, Chaudry IH. Flutamide: a novel agent for restoring the depressed cell-mediated immunity following soft-tissue trauma and hemorrhagic shock. Shock. 1997;8(4):242-8.

162. Angele MK, Wichmann MW, Ayala A, Cioffi WG, Chaudry IH. Testosterone receptor blockade after hemorrhage in males. Restoration of the depressed immune functions and improved survival following subsequent sepsis. Arch Surg. 1997;132(11):1207-14

163. Lin CY, Hsu CC, Lin MT, Chen SH. Flutamide, an androgen receptor antagonist, improves heatstroke outcomes in mice. Eur J Pharmacol. 2012; 688(1-3):62-7

\section{Submit your next manuscript to BioMed Central and we will help you at every step:}

- We accept pre-submission inquiries

- Our selector tool helps you to find the most relevant journal

- We provide round the clock customer support

- Convenient online submission

- Thorough peer review

- Inclusion in PubMed and all major indexing services

- Maximum visibility for your research

Submit your manuscript at www.biomedcentral.com/submit 